\title{
Yeni Medya, Veri Tabanı Sineması, Sinegratografi ve Greenaway'in Suitcase Sineması
}

New Media, Database Cinema, Cinegratography and Greenaway's Suitcase Cinema

\section{Serdar GEZER ${ }^{1^{*}}$}

${ }^{1}$ Ege Üniversitesi İletişim Fakültesi, İzmir / Türkiye

${ }^{1}$ Faculty of Communication, Ege University, İzmir / Turkey

*serdar.gezer@outlook.com

'ORCID: 0000-0002-8639-3831

\section{MAKALE BİLGİSI / ARTICLE INFORMATION \\ Geliş Tarihi / Date Received \\ 16.11.2019 \\ Yayın Tarihi / Date Published \\ Aralık / December 2019 \\ Kabul Tarihi / Date Accepted \\ 17.12.2019 \\ Yayın Sezonu / Pub Date Season \\ Aralık-Haziran / December - June}

\section{ATIF / CITE as}

Gezer, S. (2019). "Yeni Medya, Veri Tabanı Sineması, Sinegratografi ve Greenaway'in Suitcase Sineması" / "New Media, Database Cinema, Cinegratography and Greenaway's Suitcase Cinema”. bilar: Bilim Armonisi Dergisi, 2 (2): 87-97 doi: 10.37215/bilar.2019257650

https://dergipark.org.tr/tr/pub/bilar

Copyright (C) Published by Antalya İl Millî Eğitim Müdürlüğü Since 2018, Antalya, 07100 Turkey. All rights reserved. 


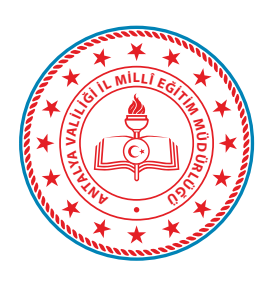

\section{ÖZET}

Son yıllarda bilgi iletişim teknolojilerinde meydana gelen gelişmeler ve ilerlemeler, kuramcılar ve teknolojinin gelişim için en temel yapı taşı olduğunu savunan yöneticiler tarafından olumlu şekilde yorumlanmasına karşın; bu ilerlemelerin yakın gelecekte nasıl bir dünyanın oluşumuna zemin hazırlayacağı da tartışılmaya devam etmektedir. Bugün 'Yeni Medya' kavramıyla kuramsallaştırılmaya çalışılan olgu her türden medyanın üretimini, depolanmasını, dağıtımını ve gösterimini tek bir araçta toplamıştır. O yüzden tarihteki bilgi iletişim teknolojileri alanında meydana gelen devrimlerden daha güçlü bir devrim olarak kabul edilmektedir. Her sanat formunu değiştirme eğiliminde olan bu olgu, normaldir ki sinema anlatı formunda da bir takım değişimlere neden olmuştur. 'Sinegratografi' ve 'veri tabanı sineması' sinema anlatı formunda meydana gelen değişimlerden bazılarını tanımlar kavramlardır. Sinema anlatısında meydana gelen bu değişimleri kendi sinema üslubunu oluştururken göz önünde bulunduran ve filmlerinin anlatısına Yeni Medyanın sunduğu geniş ifade gücünü eklemleyen Peter Greenaway, Manovich, Murray ve Ryan gibi kuramcılar tarafından Yeni Medya Sinemasının öncüsü olarak kabul edilmektedir. Bu makalede Yeni Medya kavramı tanımlanacak, yeni medyanın prensipleri üzerine farklı kuramcıların ortaya koyduğu yorumlar karşılaştırılacak ve Yeni Medya ve geleneksel medya arasındaki farklar ortaya koyulacaktır. Daha sonra Yeni Medyanın sinema anlatı formunu ne şekilde değiştirdiği ele alınacak, 'Sinegratografi' ve 'veri tabanı sineması' kavramları tanımlanacaktır. Son olarak Peter Greenaway'in Yeni Medyayı kendi sinema anlatısında nasıl kullandığı, yaptığı projeler üzerinden gösterilecektir.

Anahtar Sözcükler: Yeni Medya, Yeni Medya Prensipleri, Veri Tabanı Sineması, Sinegratografi, Greenaway.

\section{ABSTRACT}

Although advances in information communication technologies in recent years have been positively interpreted by theoreticians and executives, who argue that technology is the basic building block for development; it is also being discussed how these advances will pave the way for the formation of a world in the near future. Today, the phenomenon, which is tried to be theorized as the concept of New Media, has gathered the production, storage, distribution and display of all kinds of media in a single device. Therefore, it is accepted as a more powerful revolution than the revolutions in the field of information and communication technologies in history. This phenomenon, which tends to change every form of art, has caused some changes in the narrative form of cinema. 'Cinegratography' and 'database cinema' are concepts that define some of the changes occured in the form of cinematic narrative. Peter Greenaway, who takes these changes into account while creating his own cinema style and adds the broad expression power offered by New Media to the narrative of his films, is accepted as the pioneer of New Media Cinema by theorists such as Manovich, Murray and Ryan. In this article, the concept of New Media will be described, the remarks of different theorists on the principles of new media will be compared and the differences between New Media and traditional media will be revealed. Then, how the New Media changed the narrative form of cinema will be discussed and the concepts of 'Cinegratography' and 'database cinema' will be defined. Finally, how Peter Greenaway uses New Media in his own film narrative will be shown through his projects.

Keywords: New Media, Principles of New Media, Database Cinema, Cinegratography, Greenaway. 


\section{Gíriş}

20. yüzyılın son çeyreğinden ve özellikle 21. yüzyılın başlarından itibaren bilgi iletişim teknolojilerinde meydana gelen gelişmeler ve ilerlemeler, kuramcılar ve teknolojik gelişmeyi savunan yöneticiler tarafından olumlansa da, esasen bu teknolojilerin yakın gelecekte nasıl bir dünyanın oluşumuna zemin hazırlayacağı da tartışmaya açık bir konu olmuştur. Bugün, geleneksel medya objelerinin dijitalleştirilmesi ve dijital her türlü medyanın bilgisayar yoluyla üretimi, depolanması, dağıtımı ve gösterimi 'Yeni Medya' kavramıyla ifade edilmektedir. Yeni Medya kavramı bir takım iletişim teknolojilerini ve uygulamalarını tanımlamak üzere kullanılmaktadır (Enli 2017, 1). Yeni Medya alanında Janet Murray, Lev Manovich ve Marie Laure Ryan öne çıkan kuramcılardır. Her biri konuyu kendi perspektifinden ele almalarına rağmen Yeni Medyanın prensipleri konusunda uzlaşırlar. Onlara göre Yeni Medya "Sayısal Temsil, Modülerlik, Otomasyon, Değişkenlik ve Kod Aktarım1" gibi prensiplere sahiptir (Manovich 2001; Ryan 2006; Murray 1998; Murray 2011). Bu karakteristik unsurlar günümüz bilgi iletişim teknolojileriyle üretilen medya objelerinin ortak özellikleridir.

Yeni Medya olgusu en genel tanimiyla her türden medya metinlerinin dijital ortamda üretilmesi, yayımlanmasının ve sergilenmesinin de aynı şekilde dijital ortamda yapılması anlamına gelmektedir (Gardner 2009, 143). Yeni Medya iletişim teknolojilerinin bilgisayarlar vasıtasıyla bir araya gelerek etkileşimde bulunması ve bilgi paylaşımı yapmasıdır. 1980 öncesinde gazete, televizyon, sinema, radyo gibi analog üretimin yapıldığı medya araçları kullanılırken, günümüzde dijital radyo, dijital televizyon, dijital sinema gibi dijital teknolojinin her türden medya aracına eklemlenmesiyle oluşan medyaları kullanmaktayız (Creeber ve Martin, 2009, 2). Yeni Medya her türden medyayı etkilediği gibi hareketli görüntüyü ve hareketli görüntünün anlatım olanaklarını da etkilemektedir ${ }^{1}$. Geleneksel sinemanın anlatı yapılarına getirilen farklılık olarak 'Sinegratografi' (cinegratography) ve 'veri tabanı sineması' (database cinema) örnek kavramlar olarak gösterilebilir ${ }^{2}$ (Manovich 2001). Sinegratography, sinema anlatısının içine her türden 2D, 3D, grafik, animasyon, resim, yazı gibi elementlerin dâhil edilmesi anlamında kullanılmaktadır. 'Veri tabanı sineması' ise iki farklı şekilde ele alınmaktadır. İlki film üreticisinin filmini oluştururken çekmiş olduğu her bir planın montaja tabi tutulup son tahlilde film üretilmeden, her bir parçasının seyircinin kullanımına sunulması ve böylece seyircinin istediği parçaları seyrederek kendi filmini kendi zihninde oluşturmasıdır. Diğeri ise internet a ğlarında mevcut video parçalarının tekrar kullanılarak yeni anlatılar üretilmesidir (Manovich 2001).

Yeni Medya kuramcısı Manovich bugün bilgiye ulaşmanın, mitler ve dinler yoluyla dünyanın açıklandığı çağlara nazaran çok daha kolay olduğunu, bugün ise bilgi fazlalığı yüzünden dünyanın bütünlüklü, kapsayıcı anlatısının yapılabilmesinin zor olduğunu ileri sürüyor. Ona göre Yeni Medya kendi dilini bulmak için veri tabanlarında biriken bilginin ve kültürün hikâye formunda bize yaşadı̆̆ımız dünyanın bütünlüklü ve tutarlı bir anlatımını yapması gerekiyor. Ona göre bu yeni dil geleneksel medyanın tersine çizgisel ve hiyerarşik olmayan bir anlatıma sahip olmak durumundadır. Yeni Medya'nın sunduğu sınırsız imkânları anlatı üslubuna eklemleyen sanatçı sayısı oldukça az olmasına karşın, Manovich'e göre yaptığı projelerle bu dili en estetik şekilde kullanan sanatçı Peter Greenaway'dir (Altıntaş 2019, 3- 4).

\subsection{Peter Greenaway'in Sanatı}

Greenaway sinema dünyasında günümüzün en tartışmalı yönetmenleri arasındadır. 1942 yılında Newport, Birleşik Krallık'ta dünyaya gelmiş ve Amsterdam'da büyümüştür. Film çekmiş, videoart enstalasyonları üretmiş, resim yapmış ve görsel sanatın çoğu alanında eserler üretmiştir (Molinary 2018, 1). Dijital teknolojileri sanatında sıklıkla kullanan Greenaway 21. yüzyılın en önemli sanatçılarından biridir. Greenaway'in sanatında resim sanatı ve dijital teknolojinin sunduğu yeni imkânlar eklektik bir şekilde yer alır ve sıklıkla tarihi bilgiyle harmanlanmış kültürel motiflere yer verilir. Filmlerinde sıra dışı hayal gücünün ve ansiklopedik anlatımın yer aldığı görülür. Filmleri izleyicide yoğun olarak duygulara ve zekâ gücüne hitap eder. Filmlerinde klasik anlatı sinemasının hikâye anlatma biçimlerinden sıyrılarak farklı bir yol izler, imgelerin görsel bir düşünce oluşturma ve böylelikle bir anlam üretimi yapma yoluna gider. Bu bakımdan çalışmalarında daha çok olmuş olayları anlatmak yerine düşünceleri sunmayı ye ğler. Diğer bir ifadeyle filmlerinde olay örgüsü değil düşünce yapıları ön plandadır. Greenaway'in sanatında görsel dil çok önemlidir ve resimden kaynă̆ını alan görsel dilin, metinden kaynağını alan sinema dilini değiştirmesi gerektiğini yaptı̆̆ı filmlerle göstermektedir. Bu nedenle dijital devrimin sinema dilini değiştirerek ona yeni bir görsel dil kazandırabileceği ve böylece yenilenebileceğini düşünerek dijital devrimin savunucuları arasında yerini alır (Avcı Tuğal 2018, 417-419).

Greenaway sanat eğitimini resim alanında almış ve özellikle de tarihi olayların epik anlatımının işin içine dâhil edildiği duvar resmi alanında uzmanlaşmıştır. Duvar resmi sanatında eserin anlatımındaki aydınlatma, tarihi olaya 
yönelik ressamın yorumu, kullanılan metaforlar, materyaller, eserin sergileneceği mimari yapı ve bu yapının içerisindeki alan, sanatçının üzerinde dikkatle durduğu unsurlar arasındadır. Bu bağlamda Greenaway'in sinema üslubu aldığı eğitimden oldukça etkilenmiş görünmektedir. Onun kullandı̆̆ 1 görsel dil, imgeler ve Batı tarihini ve kültürünü anlama biçimi Batı resim sanatı ve özellikle duvar resim sanatının izlerini taşımaktadır. "Ressamın Kontrat1" (The Draughtsman's Contract, 1982) filminde resim sanatından açık izler görülebilir. Kadrajların bir yağlıboya resim tablosu gibi olduğu rahatlıkla anlaşılabilir. "Aşçı, Hırsız, Karısı ve Aşı̆ $\breve{g}^{\prime \prime}$ (The Cook, the Thief, His Wife and Her Lover, 1989) filminde Rembrandt, Vermeer ve Hals'ün eserlerine öykündüğü görülmektedir (WilloquetMaricondi, 2008, 3). Dahası onun filmleri 'canlı yağlıboya tablolar' olarak tanımlanmaktadır (Street 1997, 180). Onun, sanatını sadece tek bir araca indirgemeden, resim sanatından illüstrasyonlara, sinemadan yazarlığa kadar geniş yelpazede sanat eserleri üretmesine dayanarak, Greenaway'in bir 'hibrit-film yapımcısı' (hybrid-filmmaker) olduğu söylenebilir (Di Stefano 2008, 37). Di Stefano, hibrit-film yapımcısı kavramını sanatçının sadece film aracını kullanarak eser üretmek zorunda olmadığı, genellikle film ürettiği ama bununla birlikte sanatın diğer dallarıyla da yapıtlar verdiği sanatçı olarak tanımlamaktadır (Di Stefano 2008, 38). Greenaway de sanatın farklı dallarında eserler verdiği için bu tanımlamaya uymaktadır.

Bir söyleşisinde kendisine "sanat çevreleri tarafından postmodern-film yapımcisı olarak kabul ediliyorsunuz, ne dersiniz" dendiğinde, kendisinin yaşadı̆̆ı zamanın bir sanatçısı olduğunu, eklektik eserler ürettiğini ve 'gerçek' denen şeyden tamamıyla şüphe duyduğunu belirtmiştir (Sampson 1995, 12). Postmodern sanat formları da 'gerçek' addedilen her ne varsa ona şüpheyle yaklaşır. Postmodernizm kavramı sanayileşmenin sona erip bilgi ça ğının başlamasıyla birlikte görülen mimari, müzik, edebiyat, film, video gibi bir takım sanat formlarından oluşan kültürel üretimi tanımlamak için kullanılmaktadır. Kavram, içinde yaşadı̆̆ımız tarihi dönemle ve bu zamanın düşünme biçimi ve ekonomik yapısıyla ilişkilendirilir (WilloquetMaricondi ve Alemany-Galway 2008). Bu bağlamda Greenaway'in sanatı tam da bu zamanın eklektik üslubunu, dilini ve düşünme biçimini yansıttığ için, onun postmodern sanatçı olarak kabul edilmesi yerinde olmuştur.

Diğer yandan Greenaway "Prospero'nun Kitaplar1" (Prospero's Books, 1991), “Tual Bedenler" (The Pillow Book, 1996) filmlerinde de görüleceği üzere filmlerinde dijital teknolojiyi ağırlıklı olarak kullanır (Willoquet-Maricondi 2008, 4). Bu açıdan Manovich, Greenaway'i Yeni Medya sinemasının öncüsü olarak görmesine rağmen (Manovich 2001,
238), o kendi sinemasını 'saf sinema' (pure cinema) olarak tanımlamaktadır (Cody 1994). Yaptığ işler 'veri tabanı sinemasına' örnek olarak kabul edilebilir ancak üslubu farklı olsa da geleneksel anlamda anlatı sinemasindan da kopamamaktadir. $\mathrm{Bu}$ anlamda kendisini Sehrazad'a benzetmekte ve 1001 gece masallarında olduğu gibi hikâye anlatmaya devam edeceğini belirtmektedir (Cody 1994). "Tulse Luper'in Çantaları" (Tulse Luper Suitcase) ${ }^{3}$ projesi geleneksel sinema anlatısına devam ettiğinin bir belirtisidir. Greenaway geleneksel sinema seyircisinden farklı olarak kendi filmlerinin seyircisinin birer araştırmacı olmalarını bekler (Cody 1994).

\section{YENI MEDYA TANIMI}

Dijital teknolojilerin gelişmesiyle birlikte dijital alanda üretim yapan sanatçılar sanatlarının temel prensiplerini ve özelliklerini kuramsallaştırmaya çalışmaktadırlar. Bu çalışmalar genellikle geleneksel medyadaki hikâye anlatma biçimleriyle yeni medyadaki hikâye anlatma biçimleri arasındaki benzerlikler ve farklılıklar üzerine yoğunlaşmaktadır. Lev Manovich (The Language of New Media [2001]) hem dijital teknolojileri kullanarak sanat yapıtları üreten hem de yaptığ sanatın ve kullandığı aygıtın kuramını yazan sanatçılardan birisidir. Yeni Medya üzerine kuramsal çalışmalar yapan diğer önemli isimler Janet Murray (Hamlet on the Holodeck,1998), (Inventing the Medium, 2011) ve Marie Laure Ryan'dır (Avatars of Story, 2006). Yeni Medya olgusunu kuramsallaştırmaya çalışan bu isimler arasında farklılıklar göze çarpmaktadır.

\subsection{Janet Murray}

Murray kuramını ortaya koyarken dijital sanatçılar için yazmıştır ve Yeni Medya olgusuna onların perspektifinden bakmıştır. Ona göre sanat yapıtlarının üretiminde kullanılan araçların dijital dünyaya ait olması Yeni Medya'nın belirleyici unsurudur (Young 2014, 98). Bilgisayar kodlarının bir araya gelmesiyle oluşan bir sanat eseri bir anlam üretmektedir. Anlam üreten yapılar arttıkça kültür gelişecek, dünyayı anla kabiliyetimiz genişleyecektir. Bu bakımdan onun kuramı sosyal bilimlere katkı yahut endüstriyel üretim biçimlerine eklemlensin diye değil, tamamen hümanist bir perspektiften dijital teknolojilere bakmaktadır.

Murray'e göre dijital araçlar örneğin alfabeyle, kalemin icadıyla, baskının icadıyla, görüntü ve ses kaydının kullanılmasıyla kıyaslandığında henüz emekleme aşamasındadır. Diğerlerinin kullanıma sokulması yüzlerce yılı, yazının icadı düşünüldüğünde belki de binlerce yılı bulmasına karşın, dijital teknolojiler sadece 20-30 yıldır 
kullanılmaktadır. Bu kısa zamanda bile bu teknolojiler insanların gündelik yaşamının her alanını sarmış durumdadır. Bu bakımdan dijital teknolojiler insanların düşünme biçimlerini, dünyayı anlama biçimlerini ve birbirleriyle iletişim kurma biçimlerini belirlemektedir (Murray 2011, $2-3)$.

\subsection{Marie Laure Ryan}

Ryan Yeni Medya üzerine yazarken, medya metinlerini tüketen, izleyici, okuyucu perspektifinden konuya yaklaşmıştır. Ona göre medya metinlerinin tüketildiği araç Yeni Medya'nın belirleyici unsurudur. Yeni Medya ve bununla ilişkili yeni teknolojiler bilginin üretim, dağıtım ve yayımlanma biçimlerini etkileyerek hayatın birçok alanında potansiyel değişimlere sebep olmuştur. Bu alanlar ekonomi, sosyal ilişkiler, siyasi sistemler, bilim ve sanat, eğlence gibi insanın kimliğini, kişisel benlik algısını ve öznelliğini belirleyebilen alanlardir.

Ryan "Avatars of Story" kitabında daha çok dijital teknolojilerin anlatıya etkilerine yoğunlaşır. Geleneksel medya anlatıları edebiyat, resim, film, tiyatro gibi formlardan oluşurken; dijital teknolojilerde anlatı formları bilgisayar oyunları, hipertex, e-mail, bloglar, ve geleneksel medyanın her bir formunun dijital versiyonlarından oluşmaktadır. Bu bakımdan belki de internetin tamamı bir anlat aracı haline gelmiştir. Geleneksel anlatıların merkezine yerleşen kurgusal hikâye anlatısı yerini dijital teknolojilerdeki anlatıların merkezine yerleşen 'reality showlar'a ve kullanıcıların anlık ürettikleri kendi hikayelerine bırakmıştır (Ryan $2006,19-20)$.

\subsection{Lev Manovich}

Manovich, dijital teknoloji ve Yeni Medya'ya daha çok tarihi bir perspektiften bakarak, bugünün bir kuramını ortaya koymuştur (Young 2014). Yeni Medya'nın geleneksel medyadaki metinlerden, bunların iletimin biçimlerinden nasıl farklı olduğu, bu dönüşümün zaman içerisinde nasıl değişime uğradığına yoğunlaşmıştır. Bu kuramcılardan her biri Yeni Medya'nın tanımı üzerine birbirine yakın düşünceler ortaya koymalarına rağmen, Yeni Medya'nın prensipleri konusunda çok küçük nüanslarla birbirlerinden ayrılmaktadırlar.

Yeni Medya, Manovich'e göre gösterimle ilgili bir olgu olarak tanımlanmaktadır. Yeni Medya ona göre, üretimden ziyade, dağıtımı ve gösterimi bilgisayar yoluyla yapilan sanat yapitları olarak tanımlanır. Örneğin fotoğraf bilgisayarda üretilip gösterildiğinde yeni medya objesi iken, aynı fotoğraf kâğıda baskısı yapıldığında ve o şekilde gösterimi yapıldı̆̆ında geleneksel medya objesi olarak değerlendirilmektedir (Manovich 2001). Veya bir yazı/metin Word programında üretilip kitaba basıldığında ve okuyucunun karşısına basılı bir kitap formunda çıktığında geleneksel medya objesi iken, aynı eser internette bir web sayfasında, bir blokta yayımlandığında yeni medya objesi olarak değerlendirilmektedir.

Diğer yandan Yeni Medya kullanıcıdankullanıcıya veya kullanıcıyla-bilgi arasındaki etkileşimi mümkün kılan iletişim teknolojileri olarak tanımlanır. Bu tanımlamada öne çıkan husus geleneksel kitle iletişim araçlarındaki bir göndericiden kitlesel tüketiciye ulaşan tek yönlü kanalı ihtiva eden iletişim modelinin yerine internet kanalı kullanılarak kitleselden kitlesele akan bilgi yoluyla etkileşimin koyulmasıdır. Dolayısıyla Yeni Medya insanların iletişim ve etkileşim modelini tümüyle değiştirebilmektedir. Bu açıdan kavram teknolojik, sosyal ve kültürel değişimleri bütünüyle kapsama potansiyeli taşımaktadır (Lister 2003; Manovich 2003; Rice 1999).

Yeni Medya olgusu esasen bilgi iletişim teknolojilerinde yakın geçmişten günümüze kadar meydana gelmiş teknolojik devrimlerden bir tanesidir. Bilgi iletişim teknolojilerindeki devrimler her bir medyanın üretimi, depolanması ve dağıtımı/sunumu gibi bir ya da iki boyutunu etkilemiştir. Örneğin, baskının icadı yazının dağıtımını etkilemiştir. Fotoğrafın icadı ise sadece resmi etkilemiştir. Diğer yandan bugün yaşadı̆̆ımız bilgisayar medya devrimi iletişimin bütün boyutlarını etkilemiştir. Yani hem medyanın elde edilmesi, düzenlenmesi ve depolanması hem de yayınlanmasını etkilemiştir ve ayrıca bütün medya tiplerini de etkileyebilmiştir (yazı, resim, fotoğraf, hareketli görüntü, ses gibi) (Manovich 2001, 20). Dolayısıyla 21. yüzyılda yaşanan bilgi iletişim teknolojilerindeki devrim bu güne kadar yaşanmış devrimlerden çok daha kapsamlı etki alanına sahiptir. Bütün medya tiplerini ve her bir medya boyutunu tamamen etkileyerek, bunlarin hepsini birleştirmiş ve bilgisayarlarda üretilebilir, depolanabilir, gösterilebilir kılmıştır.

\section{YENI MEDYANIN PRENSIPLERI}

Yeni Medya olgusunun diğer medya devrimlerinden farklı olarak kendine has bir takım prensipleri vardır ve bu prensipler Yeni Medya kuramciları tarafindan ortaya koyularak kuramsallaştırılmıştır. Her bir kuramcı bazı prensiplerde anlaşırken bazı bir takım prensiplerde kendi bakış açısına göre farklı yorumlarda bulunmuştur. Uzlaşılan Yeni Medya prensipleri beş ana başlikta toparlanabilir (Manovich 2001; Ryan 2006; Murray 1998; Murray 2011). 
1-Sayıal Temsil (Numerical Representation): Bütün Yeni Medya objeleri ister bilgisayarda üretilmiş küçük bir çizgi olsun ister analog medyadan dijitale aktarılmış medya objesi olsun sayısal olarak temsil edilmektedir. Yeni Medya objesi matematik olarak tanımlanabilir hale gelmiştir. Bunun yanında Yeni Medya objesi algoritmik manipülasyon nesnesidir. Yani Yeni Medya objesine, uygun bir algoritma uygulandı̆̆ında o obje üzerinde çeşitli değişiklikler yapılabilmektedir. $\mathrm{Bu}$ da medyanın programlanabildiği anlamına gelir (Manovich 2001, 27). Örneğin bir dijital fotoğrafa çeşitli yazılımlar kullanılarak algoritmik manipülasyon uygulandığında o fotoğraftan hemen kir, pas, çizgi kaldırılabilir. Ya da mevcut dijital kameraların yazılımları güncellendiğinde, çözünürlüğü (resolution) öncekinden daha yüksek fotoğraflar elde edilebilmektedir. Ryan'a (2006) göre ise sayisal temsil Yeni Medya objesinin farklı tabakaların bir araya gelmesiyle oluşması anlamında kullanılmaktadır. Örneğin fotoğraf, yazı, animasyon veya sesin tek bir Yeni Medya objesinde birleştirilmesi gibi.

2-Modülerlik (Modularity/Fractal Structure of New Media): Medya elementleri-imaj, ses, şekil vb.ayrı ayrı parçalardan oluşurlar (pixels, poligons, voxels, characters, scripts). Bu elementler büyük parçaların içinde bulunabilmelerine rağmen ayrı ayrı kimliklerini devam ettirebilirler (Manovich 2001, 30). Modülerlik prensibini Ryan (2004) da aynı şekilde tanımlamıştır. Örneğin bir Yeni Medya objesi olan multimedya filmi binlerce fotoğraftan oluşabilir ve her bir fotoğraf kendi kimliğini devam ettirebilir. Bu fotoğraflar ise pixeller ya da voxeller'den oluşur ve onlar da ayrı ayrı müdahaleye açıktır. Yani o filmdeki bir fotoğraf, belirli yazılımlar kullanılarak en küçük parçasına kadar manipülasyona tabi tutulabilir.

3-Otomasyon (Automation): 1. ve 2. prensipler otomasyonu mümkün kılmışlardır. Yeni Medya elementi ister bilgisayarda üretilmiş ister analogdan dijitale aktarılmış olsun, medya elementindeki insan müdahalesinin az ya da çok dişlanması, otomasyon olarak tanımlanmaktadir (Manovich 2001, 32-44). Ryan'a (2006) göre bu, medyanın programlanabilmesi olarak tanımlanırken, Murray'a (1998, 2011) göre ise bilgisayar yoluyla süreçlerin uygulanması olarak tanımlanmaktadır (aktaran Young 2014). Örneğin; Photoshop'ta bir resmi tarama yaparken kullanılan yazılım otomatik olarak çizgileri kaldırabilir veya belli bir renk skalasıyla tarama işlemini gerçekleştirebilir. Ya da Hollywood'da filmlere hemen eklenen önceden hazırlanmış ve yazılıma dâhil edilmiş 3-D objeler (örneğin; ağaçlar, kuşlar, ya da kalabalık insan grupları gibi objeler) insan müdahalesini dışlamaktadır. Bunlar 'Artificial Life' [AL] programında hazır olarak bulunmaktadır. Bütün kuramcıların uzlaştığı genel tanım olarak Yeni Medya objesinin üretiminde insan müdahalesinin en aza indirgenmesi otomasyon prensibidir.

4-Değişkenlik (Variability): Yeni Medya objesi sonsuza kadar sabitlenmiş bir obje değildir aksine farklı ve sonsuz sayıda versiyonu olabilme kabiliyetinde bir objedir. Geleneksel Medya insan üretimi olduğu için yazı, resim ve ses belli bir sırayla düzenlenmiş ve ortaya sonsuza kadar değiştirilemez bir bütün çıkmıştır. Bu bütün elbette kopyalanabilir, çoğaltılabilir, ama bütün olarak kopyalanabilir. Diğer yandan Yeni Medya objesi aynen kopyalanabileceği gibi, farklı versiyonlarla da çoğaltılabilir. Örneğin bir Web sayfası kalıbı (template) sinırsız sayıda ve farklı versiyonlarda tekrar tekrar üretilebilir (Manovich 2001, 32-44). Ryan (2006) bunu hızlı şekilde değiştirilebilir çıktılar/ürünler olarak tanımlamaktadır. İki kuramcı da değişkenlik prensibini benzer şekilde ele almışlar ve Yeni Medya objesinin aynı kalitede sayısız farklı versiyonlarının üretilebilmesine vurgu yapmışlardır.

5-Kodaktarım1 (Transcoding): Kod aktarımı prensibinden yalnızca Manovich (2001) bahsetmektedir. Ona göre 'bilgisayarlaştırma' (computarization), medyanın bilgisayar verisi haline getirilmesi demektir. 'Bilgisayarlaştırılmış medya' (computarized media) insanlar için bir anlam ifade eder. Örneğin; bir fotoğraf ya da gramer kurallarına uyularak üretilmiş olan bir yazı bilgisayarda gösterildiğinde insanlar için anlamı olan objelerdir. Mesela bilgisayardaki bir fotoğraf insan kültürüne aittir ve diğer insani kültürlerle diyaloğa girebilir. Başkasının kültüründe belli bir objenin resmi başka anlama gelebilir, bizim kültürümüzde tamamen farklı bir anlama gelebilir.

Diğer yandan onlar aslında bilgisayardaki
renk değerlerinin, dosya boyutunun,
sıkıştırılma kombinasyonlarının içerildiği veri organizasyonlarıdır ve sayısal temsillerden, bilgisayar yazılımlarından oluşmaktadırlar. Bu da diğer bilgisayarlarla iletişime geçebilir. Yani aynı dijital fotoğraf bir bilgisayardan diğerine gönderildiğinde bu veri organizasyonları aktarılır.

İşin bu boyutu düşünüldüğünde Yeni Medya objesinin iki katmanı (layer) vardır. Bunlardan ilki Kültürel Katman (Cultural Layer), ikincisi Bilgisayar Katmanıdır (Computer Layer). Doğal olarak Yeni Medya bilgisayarda üretilip, depolanıp, da ğıtıldı̆̆ için bilgisayar mantığının (computer logic) kültürel katmanı, kültürel katmanın da bilgisayar mantığını büyük oranda etkileme kapasitesi vardır. Bilgisayar oyunlarının insan kültürü temel alınarak üretilmesi ya da akıllı telefonlarda fotoğrafın boyutunun değiştirilirken iki parmak kullanılması bu iki katmanın birbirini etkileme biçimine örnek olarak gösterilebilir. 


\section{GELENEKSEL MEDYA VE YENI MEDYA ARASINDAKI FARKLAR}

Geleneksel Medya ve Yeni Medya arasındaki bariz farkları Manovich (2001) ortaya koymaktadır. Ona göre Yeni Medya analog medyanın dijital temsilidir. Sürekli olan analog medyanın tersine, dijital olarak üretilmiş medya parçalı ve ayrıktır. Yani modülerlik prensibinde de bahsedildiği gibi Yeni Medya objesi en küçük parçalarına kadar ayrılabilir ve müdahaleye açıktır.

Bütün dijital medya (text, image, visual, audio, 3D) aynı dijital kodu paylaşır. Bu da bütün bu medyanın tek bir araçta gösterilmesine olanak sağlar, o araç da bilgisayardır. Tabi günümüzde tabletler, akıllı telefonlar da bu kapsamda değerlendirilir.

Yeni Medya elementine istenildiği zamanda ve istenilen kısmına ulaşım sağlanabilir. Analog medya sekanslardan oluşan ardışık bir yapıda olduğu için bu imkânı sağlayamaz. Örneğin; film, video gibi medyanın geleneksel yollarla gösterimi yapıldığında, medyanın istenilen zamanına veya kısmına ulaşım mümkün değildir.

Analog medya kopyalandığında kalitesi düşerken dijital medya sonsuz sayida kopyalanabilir ve kalitesi düşmez.

Yeni Medya interaktiftir. Geleneksel Medyada temsilin bir sirası vardir ve kullanıc1 o sirayla kullanır ya da maruz kalır. Yeni Medyada ise kullanıc1 objenin istediği anda istediği kısmına kolaylıkla ulaşabilir ve medyayı istediği sıra ile okuyabilir, seyredebilir. Böylece eserin üreticisinin uygun gördüğ̈̈ sıra yerine kendi orijinal sırasını belirleyebilir, bu da ortaya her bir kullanıcıya göre değişen her biri ayrı sekanslarda medyanın üretilmesi anlamına gelmektedir. Dolayısıyla sanatçının eseri ve seyircisi üzerindeki iktidarı zayıflatılmıştır.

\section{SiNEGRATOGRAFi (CINEGRATOGRAPHY) / (CINEMATIC AND GRAPHIC)}

'Sinegratografi' (cinegratography) kavramı Manovich (2001) tarafından Yeni Medyada anlat imkânlarıile geleneksel medyadaki anlatı yapılarının karşılaştırılması için kullanılmıştır. Ona göre bilgi iletişim teknolojilerinde ve buna paralel ve sarmal olarak Elektronik ve Dijital teknolojilerde meydana gelen gelişmeler medyada büyük değişimlere neden olmuştur ve bu değişimler her geçen gün hıla devam etmektedir. Özellikle hareketli resimler yani sinema ve televizyon alanında bu değişimlerin etkileri görülmektedir. Teknolojideki hızlı değişim medya anlatı yapılarının değişmesine neden olmaktadır.

1980’lerin başına kadar hareketli görüntü anlatısı lineer anlatılardan oluşmaktaydı. Bu tarihten itibaren lineer anlatının dışında bir anlatı formu ortaya çıkmaya başladı. Sinema salonlarında değil de daha çok televizyon ve bilgisayar ekranlarında seyredilen bu formlar, sinematik gerçeklikten uzak lineer olmayan formlard.

Bunlardan ilki müzik videolarıydı. Elektronik video-efekt makinalarının stüdyolara girmesiyle biçim (form) değişikliği başladı. Bu videoların kendi içinde bir anlatısı olmasına rağmen bu anlatı geleneksel video anlatısının dışında, lineer olmayan bir anlatıya sahipti. Bu form sayısı yeni anlatı imkânlarının ortaya çıkarılabileceği bir laboratuvar gibiydi. Fotoğrafik imajların manüpilasyonu, 2D, 3D imkanlar, kolaj, resim gibi formların nasıl videoda kullanılabileceğinin adeta bir çalışmasıydı. $\mathrm{Bu}$ formlarda resimlerde üst üste bindirmeler, grafik unsurlar, yazılar, farklı sekansların iç içe kullanılması gibi teknikler kullanılmakta ve anlatı bu şekilde kurulmaktaydi.

Diğer bir lineer olmayan form ise CD-ROM tabanlı bilgisayar oyunlarıydı. Bu form müzik videolarının aksine tamamı bilgisayarda üretilen formdu. Bu oyunlardaki anlatı da kullanıcıya göre biçimlenen ve her türden medyanın oyunun içinde kullanıldı̆̆ 1 yapılardı.

Buna ilave olarak geleneksel medya ürünlerinin bilgisayarlarda gösterilmesi yaygınlaştıkça bilgisayar üreticileri bu medyanın sorunsuz gösterimi için çareler aramaya başladı. Örneğin, Apple 1991'de Quicktime Player'1 piyasaya sürdü. Bu gibi yazılımlarda ilk yillarda bazı sorunlar yaşandı. Filmlerin dosya boyutları büyük olduğu için o günkü bilgisayarlar bu dosyaları tam ekran oynatmakta sorunlar yaşadı. Bu sorunlar medya üreticilerinin de eserlerini üretirken üzerinde düşünmeye başladığı sorunlardı. Bu yüzden tasarımcılar da bir yandan farklı bir sinema dili kullanmak zorunda kaldılar. Üst üste bindirmeler (superimpose), tekrarlar (loop) ve değişik efektler kullanılmaya başlandı. Bu farklı dil git gide sinematik yanılsamayı (illüzyon) daha sentetik-yapay bir yerden 'grafikten' beslenmek zorunda biraktı. Dolayısıyla sinema, animasyon ve grafikle bilgisayar ekranında tekrar buluştu. Çünkü öncesinde Avangard (avant-garde) sinemada grafik kullanılmaktaydı. Böylece modern sinema teknikleri ve 19'uncu yüzyıl sinema seyir geleneği birleşti ve hibrit bir yapı olan dil ortaya çıktı. Sinegratografi kavramı bu yapıyı tanımlamak için kullanılan kavram haline geldi. Tabi ki bu birleşme Yeni Medya anlatılarının da teknik boyutuna gönderme yapar niteliktedir ve her türlü verinin anlatıyı oluştururken dikey ve yatay kullanımını yani üst üste (superimpose) ve yan yana (montaj) 
kullanımını mümkün kılmış, anlatıyı genişletmiştir.

\section{VERI TABANI SINEMASI (DATABASE CINEMA)}

Film çekimi sırasında sayısız bilgi ortaya çıkar. Her bir çekim, her bir plan toplamda inanılmaz veri üretir. Eğer geleneksel medya kapsamında düşünürsek her sinemacı bu verilerden, yani muhtemel sayısı alternatif filmden birinin izinden gider ve çizgisel (lineer) anlatıya sahip bir film üretir. Borges'in 'Yolları Çatallanan Bahçe' sinde olduğu gibi her bir farklı hikâye aslında mümkündür, ama sinemacı bu hikâyelerden bir tanesini tercih eder ve onu üretir.

Nishant Shah'ın (2009) mikro sinema formları üzerine yazdığı makalede amatör videoların ve mobil araçla çekilip internet üzerinden dağıtılan videoların tekrar kullanılması üzerine bir inceleme bulunmaktadır. İnternette hazır olarak var olan ve diğer veri tabanlarında mevcut videoların tekrar kullanılarak bir anlatı üretilmesi 'veri tabanı sineması'nın bir örneğini oluşturmaktadır. Bu formlar ve anlatılar, çok hızlı üretilip, yayılıp, görülüp, yorumlandığı için geleneksel 'üreticiizleyici/tüketici' ilişkisini yerle bir etmektedir.

Kim Mui Elaine Chan'e (2009) göre ise sinematik bakış (gaze) artık sinema salonlarından üretilmemektedir. Daha çok bilgisayar ekranlarından, telefonlardan, oyun konsollarından ve tablet ekranlarından üretilmektedir. Sinema izleyicisi yerini interaktif izleyiciye bırakmıştır. $\mathrm{Bu}$ da oyun dünyasına ait bir kavramdır. İzleyici alışkanlıklarının değişmesi, izleme şekillerinin değişmesi sinema geleneklerini de tekrar tanımlamaktadır.

Greenaway bu noktada 'anlatı' ve 'veri tabanı' kavramlarını bir araya getirmeye çalışan ilk yönetmendir. Lineer bir anlatıdan ziyade bütün veriyi olduğu gibi kullanır. Sanatının gösterimini de Yeni Medya'nın sunduğu bütün araçları kullanarak yapar. Bu; film parçaları, kitaplar, sergiler, internet sitesi, müzeye veya bütün şehre yayılmış bir veri tabanı ve gösterim alanı olabilir. Manovich (2001)'e göre tam olarak Greenaway'in sanatı da budur. Bütün verileri mekâna yaymak. Yani her bilgiyi alana dağıtmak.

Örneğin; 1992'deki “Dünyayı temsil eden 100 obje" (100 objects to represent the World) projesinde Greenaway dünyayı anlatan 100 obje seçer ve bunları Viyana Güzel Sanatlar Akademisinde sergiler. Amerikalılar tarafından içerisinde dünyadaki yaşamı temsilen seçilen 100 objeden oluşan uzaya bir roket gönderilmiştir. Greenaway bu rokete koyulan objelerin bizi ve dünyadaki yaşamı temsil edip etmediği konusunda bizim fikrimize başvurulmadı̆̆ı düşüncesinden hareketle, eğer kendisine sorulsa idi dünyayı anlatan 100 obje ne olurdu sorusunun cevabi olarak bu projeyi tasarlar. Sergi daha sonra dünyanın farklı şehirlerini dolaşır. Sergideki objeler arasında 'makine', 'diş', 'Willendorf Venüsü'4 olmak üzere cansız objeler ve bunun yanında 'öpücük', 'ruh', 'uyku', 'bulut', 'rüzgâr' gibi canlandırma yoluyla gösterilmeye çalışılan objeler yer almaktadır. Di Stefano'ya göre bu sergide Greenaway'in yaptığ 1 bir deneme, soyut bir konseptin veya tam olarak kavranamaz bir objenin filmsel araçlar kullanarak görünür hale getirilmesidir. Örneğin 'bulut' büyük formatta bir aydınlatma yapılarak ve gök gürültüsü seslendirmesi kullanılarak sahnede sergilenebilir hale gelmiştir. Bu deneme aynı zamanda filmsel aygıtların bir anlamda gücünü de ortaya koymuştur (Di Stefano 2008, 46).

Diğer yandan Greenaway anlatıyı da tamamen terk etmez. Örneğin; 1995'te “Merdivenler: Münih Projeksiyonu" (The stairs: Munich Projection) projesinde, $\quad 100$ tane projeksiyonu Münih sokaklarına koyar ve her biri sinemanın 1 yılını anlatmak üzere projeksiyondan gösteri yapar. Bu projede anlatıyı alana yaymak fikrinden hareket eder (Cody 1994). Her ne kadar Greenaway Yeni Medya kuramcıları tarafından Yeni Medya Sinemasının öncüsü olarak dillendirilse de onun sinema anlayışı 'sinegratografi' ve 'veri tabanı' sinema formlarından biraz farklıdır (Gardner 2009). O ikisinden birini değil her ikisini de kullanmay1 tercih eder.

\section{GREENWAY'IN SUITCASE SINEMASI}

'Greenaway'in Suitcase sineması' (Greenaway's Suitcase Cinema) kavramı ilk kez Jared Gardner (2009) tarafından kullanılmıştır. Gardner'a göre Greenaway'ın yaptığı işler Yeni Medya sinemasından farklıdır, o daha çok Greenaway'ın kendisini de tanımladığı şekliyle 'Saf Sinema' (Pure Cinema) yapmaktadir.

Hawthorne 1997'de Peter Greenaway'le yaptı̆̆ 1 röportajda Greenaway, sinemanın 30 yildır can çekiştiğini söylemiştir. Ona göre; Godard her şeyi mahvetmiştir, parçalara ayırmış ve sinemayı kendi bilincinde (self-conscious) bir hale sokmuştur. Bütün estetik hareketlerde, teorilerde olduğu gibi, sinema da üç kuşak boyunca sürmüştür. Dede her şeyi oluşturur, organize eder, baba elde edileni sürdürür, genç torun ise her şeyi parçalar ve batırır (Hawthorne 1997). Ona göre Godard her şeyi mahveden torundur.

1997'de bu tür düşünceler modadır, insanlar 'sinemanın ölümü' üzerine kariyer yapmışlardır, hatta akademide bundan nasibini almıştır ve bu mesele çok dillendirilen bir konu haline gelmiştir. Sebep olarak da yeni medyanın gelişimi, dijital 
üretim, dağıtım ve gösterim sunulmaktadır. Şimdilerde ise Yeni Medya kuramcıları, Greenaway'i 'Post-Sinema'nın babası olarak görmektedir (Manovich 2001).

Yeni Medya kuramcisı Lev Manovich (2001) ve diğerleri için, 'sinemanın sonu' söylemi, anlatı yapılarının tiranlığından kurtuluş anlamına gelmektedir. İlk defa seyirci çizgisel (lineer) ya da hiyerarşik olmayan bir şekilde görüntüyü, sesi, metni görmektedir. Böylece anlatı ve seyirci ilişkisi yerini film üreticisi ve son kullanıcıya bırakan interaktif bir sinema anlayışı ortaya çıkmıştır.

Jared Gardner'ın (2009) aktarımıyla Greenaway'e göre bugün dijital film yapımının ortaya çıkışı 'post sinema' söylemi ile değil de 'saf sinema' (pure cinema) kavramılla tanımlanmaktadır. Yani ilk dönem sinemanın kullanılmamış, yanlış yöne kanalize olmuş potansiyelinin geri kazanılması anlamındadir.

Holly Wills'e göre Greenaway seyirciyi zorlayarak onların seçmesini, birleştirmesini isteyerek 'veri tabanı anlatısı' (database narrative) ile bir sürü bilginin içinden hikâyeyi çıkarmasını, anlamasını sağlar (aktaran Gardner 2009). Tabi ki bu noktada her bir izleyici sayısı kadar anlatı ortaya çıkmaktadır. Bu anlamda Greenaway'ın 1992 yılındaki "Dünyayı temsil eden 100 obje" (100 objects to represent the World) sergisi ve "Merdivenler: Münih Projeksiyonu" (The stairs: Munich Projection) projesi 'veri tabanı anlatısı'na (database narrative) örnektir.

Greenaway’ı her röportajında da belirttiği gibi, dijital devrim olumlanması gereken bir devrimdir ve 100 yillik sinema tarihi aslinda sinemanın girişidir. Saf Sinema (pure cinema) yeni başlamaktadır. Ona göre saf sinema, geleneksel anlatı sinemasının (narrative cinema) reddettiği bütün özgürlükleri içinde barındıran ve seyirciye bütün malzemeyi veren, onu ortak üretici haline getiren bir sinemadır. Bu tanım onun “Tulse Luper'in Çantaları" (Tulse Luper Suitcases) ${ }^{5}$ projesinin de temelini oluşturmaktadır.

“Tulse Luper'in Çantaları" projesi çanta metaforu üzerinden işler. Çantalar başka çantaları barındırır. Vaat edilen şey ise: Luper arkasında çantalar bırakır ve bunlar teker teker araştırılmalı ve Luper'in hayatının tamamı ortaya çıkarılmalıdır.

“Tulse Luper'in Çantaları" nın ilk filmi 2003 yilında gösterime giren "Moab Öyküsü" (Moab Story)'dür. Luper'in ilk çantayı nasıl oluşturduğu anlatılmaktadır. Babası genç Luper'i demir madeninde kapalı tutmaktadir. O da orada bir takım objeler toplar.

$\mathrm{Bu}$ noktada da kendisini Gardner'in aktarımıla Şehrazad'a benzetir. Şehrazad'ın 1001 gece masallarında yaptı̆̆ı gibi, O da sürekli hikâye anlatmaya devam edecek yoksa ölecektir. Hikâyelerinin bir amacı olmasa da o anlatmaya devam edecektir. Fakat 1001 gece masallarının bir sonu vardır. 1001'inci hikâye sonuncudur. Ama Yeni Medyada veri tabanı anlatısı (database narrative) formu ile bu sınırsız bir yapıya imkân sağlamıştır. Sınırsız kişiye erişim imkânı ve özgürlük.

Greenaway geleneksel anlatı sinemasinın her bir yapısına açık bir karşı duruş sergilemektedir. Bu karşı duruş Lumiere Kardeşler'in kamerasıyla çektiği 1 dakikalık kısa filmde de görülebilir. Sinemanın 100'üncü yılını kutlamak için dünya sinemasının önde gelen 40 yönetmenine Lumiere Kardeşlerin orijinal ekipmanıyla 1 dakikalık film çekmeleri istenmiştir. Greenaway'ın yaptı̆̆ 1 film içlerinde tek çoklu çekimin montajiyla yapılandır. Diğerleri Lumiere Kardeşlerin yaptı̆̆ gibi, 1 dakikalık tek plan çekimi yapmışlardır. Greenaway'in filmi ilerledikçe yılların rakamsal temsillerinin ardı sıra aktığı görülür ve filmde bir erkek karakterin 3 farklı çekimi yer alır. Lumiere kardeşlerin kamera ekipmanı, çantasıyla beraber Lumiere kardeşlerin portresinin önünde gösterilir. Greenaway'e göre Lumiere'lerin ekipmanında yeni bir hayat, yeni bir enerji yoktur. Sadece ölümlü bir insan bedeni, ve tabut olarak da ekipman ve çantası vardır (Gardner 2009). Greenaway'e göre sinema Lumiere'ler yüzünden asıl potansiyelini kaybetmiş, faşist bir yapıya bürünmüştür.

Yeni Medya kuramcılarının onu öncü olarak görmelerine rağmen Greenaway geleneksel anlatı sinemasının dört tiranlığına 'hikâye, kadraj, aktör, kamera' karşı çıkan bir sanatçı olarak Yeni Medyanın bizi özgür kılacağına inanmamaktadır. Tekrar tekrar sinema ve anlatıya geri dönerek, özgür kalmayı da çok ehemmiyetli görmemektedir. Aynı Tulse Luper'in kendisini tanımladı̆̆ gibi; tutsak ve kollektör, yani koleksiyoncu olarak kendisini tanımlar. Ve tüm hayatını tutsaklıkta sanat yapan olarak kurar (Gardner 2009). Bu yüzden Yeni Medyanın anlatı imkânlarını kullanmasına rağmen geleneksel sinemadan da kopamamaktadır. "Tulse Luper'in Çantaları" (Tulse Luper Suitcase) projesinin içerisinde yer alan 4 farklı sinema filmi geleneksel anlatı yapılarını kullanmasa da filmlerin her biri ve tamamı bir hikâye anlatır. O da Tulse Luper karakterinin hikâyesidir.

“Tulse Luper'in Çantaları" Projesinde yer alan filmler şunlardır:

- 2005 Tulse Luper 'A Life in Suitcases'. 120 dk. Dünya Gösterimi: Cambridge Film Festival. Festivals \& Markets. 2005 International Film Festival Cannes

- 2004 The Tulse Luper Suitcases, Part 3: From 
Sark to the Finis. $120 \mathrm{dk}$. Dünya Gösterimi: Venice Film Festivali Üçleme film gösterimi (7 saat). Film Festivalleri: Montreal, Haifa, Thessaloniki, Sophia, Scopje, Osnabruck, etc.

- 2004 The Tulse Luper Suitcases Part 2: Vaux to the Sea. 108 dk. Dünya Gösterimi - Berlin Film Festival

- 2003 The Tulse Luper Suitcases Part 1: The Moab Story. 127 dk. Dünya Gösterimi Cannes Film Festivali Yarışma Bölümü. Film Festivalleri: Cambridge, Edinburgh, Sitges, Naples, Ischia, Toronto

Onun sineması seyirciye imkânsız sorular sorduran araştırmacı olmasını, neden bu objeler, neden bu siralama gibi sorular sorulmasın istemektedir.

Çevrimiçi oyunda ise oyuncuların Tulse Luper araştırmacısı olmaları, farklı bulmacaları çözerek ve bazı objeleri toparlayarak büyük resmi oluşturmaları beklenmektedir.

\section{SONUÇ VE TARTIŞMA}

Bilgi iletişim teknolojilerindeki gelişmeler her türden medyanın üretim, depolama ve dağıtımını etkilemesinin yanında her türden sanat yapıtında da kökten değişimlere sebep olmaktadır. Bunlardan biri de hareketli görüntünün anlatı yapılarında meydana gelen değişimlerdir. Esasen anlatı yapılarındaki değişimlerin örnekleri avangard sinemada görülmekteyken, özellikle müzik videoları ve bilgisayar oyunlarının yaygınlaşmasıyla sinema ve televizyon metinlerinin anlatı yapıları da farklı bir yöne doğru evrilmiştir.
Bugün Yeni Medya kavramıyla kuramsallaştırmaya çalışılan olgu her türden medyanın üretimini, depolanmasını, dağıtımını ve gösterimini tek bir araçta yani bilgisayarda toplamıştır. O yüzden tarihteki bilgi iletişim teknolojileri alanında meydana gelen devrimlerden daha güçlü bir devrim olarak kabul edilmektedir. Yeni Medya olgusunu kuramsallaştırmaya çalışan önde gelen üç kuramcı vardır. Bunlar; Janet Murray, Lev Manovich ve Marie Laure Ryan'dır. Bu kuramcılar Yeni Medyanın prensiplerini ortaya koymuşlardır. Her sanat formunu değiştirme eğiliminde olan bu olgu, normaldir ki sinema anlatı formunda da bir takım değişimlere neden olmuştur. 'Sinegratografi' ve 'veri tabanı sinemas1' sinema anlatı formunda meydana gelen değişimlerden bazılarını tanımlar kavramlardır. Günümüzde, Peter Greenaway, Yeni Medya kuramcıları tarafından Yeni Medya Sinemasının öncüsü olarak kabul edilmektedir. Greenaway ise kendi sinemasını Yeni Medya Sineması olarak değil de 'saf sinema' olarak tanımlamaktadır. Greenaway geleneksel medyanın sınırlılıklarını Yeni Medya'nın imkânlarını kullanarak aşan ve Yeni Medya'nın karakteristik unsurlarını sanatının üslubuna eklemleyebilen bir sanatçıdır. Gerçekleştirdiği projeler ve yaptı̆̆ filmler yoluyla Yeni Medya anlatısının olanaklarını bizlere göstermiştir ve bu yönüyle Yen Medya sanatçılarına öncülük etmiştir. Onun "Tulse Luper'in Çantaları" projesi Yeni Medya anlatısı formunun, veri tabanı sineması formunun öncü örneği olmuştur. Greenaway'dan öğrendiğimiz bir şey varsa, o da, her geçen gün hızla ilerleyen ve gelişen bilgi iletişim teknolojileri her türden sanat yapıtını da değişime maruz bıraksa da sinema anlatısı kendi formunu Yeni Medya'nın sunduğu imkânları da içine alarak devam ettirecek gibi görünmektedir.

\section{NOTLAR}

1. Yeni Medya kavramına ilişkin daha ayrıntılı bilgi “Yeni Medya'nın Tanımı” başlığı altında açıklanmaktadır.

2. Bu iki kavram "Sinegratografi (Cinegratography)/(Cinematic and Graphic)" ve "Veri Tabanı Sineması (Database Cinema)" başlıkları altında daha detaylı olarak açıklanmaktadır.

3. 'Tulse Luper'in Çantaları' projesi, Greenaway'ın tasarladığı bir film karakteridir. Luper kendini profesyonel bir tutuklu olarak tanımlayan ve dünyanın değişik yerlerine 92 tane çanta saklamış bir karakterdir. Bu çantalardan her biri dünyayı temsil etmek, göstermek için tasarlanmış farklı hikâyelere sahiptir. Bu bir multimedya projesidir ve 4 uzun metraj film, sergiler, kitaplar, $92 \mathrm{CD}$, Web sitesi ve video oyunundan oluşur (tulseluperjourney). Bu makalenin "Greenaway'in Suitcase Sineması" başlığı altında hem Greenaway sineması hem de 'Tulse Luper'in çantaları' projesiyle ilgili daha detaylı bilgi verilmektedir.

4. Willendorf Venüsü $11 \mathrm{~cm}$ boyunda, yaklaşık 30 bin yıl yaşında olduğu düşünülen oldukça geniş hatlara sahip kadın heykelidir. Taş devrine ait olduğu düşünülmektedir. Günümüzde Viyana Doğa Tarihi müzesinde sergilenmektedir (visitworldheritage).

5. Tulse Luper Greenaway'1n 29 Ekim 1911'de doğmuş olan kurgusal bir kahramanıdır. Projenin amacı Tulse Luper'in yaşamının 
1928-1989 yılları arasında kalan dönemini dünyanın farklı yerlerine sakladığı 92 adet valiz yoluyla açı̆̆a çıkarmaktır. Luper'in hayat hikâyesinin sıkıştırıldı̆̆ı tarihin önemi ise şudur: 1928 yılında Colorado'da uranyum çıkarılmaya başlanmış, 1989 yılında ise Berlin
Duvarı yıkılmıştır. Valiz sayısı olan 92 ise uranyumun atom numarasidır. Greenaway uranyum çağı olarak adlandırdığ 20. Yüzyılın Luper'in hayatı üzerinden alternatif bir tarihini yazmaktadır (Altıntaş, 2019, 2).

\section{KAYNAKLAR}

Altıntaş, G. (2019). "Greenaway ve Veritabanı Sineması". Erişim adresi: https://www.academia. edu / $38627606 /$ Greenaway_ve_Veritaban\%C4\%B1_ Sinemas\%C4\%B1. Erişim Tarihi: 4.12.2019.

Avcı Tuğal, S. (2018). "21.Yüzyıl Çağdaş Sanat Önermesi Olarak Peter Greenaway'in Last Supper Dijital Video Enstalasyonu”. Art-Sanat, 2018 (9).

Chan, K. M. E. (2009). 'Transformation of visual culture in relation to the spatial experience of postmodern flaneurs: the impact of MMORGs on contemporary Chinese cinema'. Journal of Chinese Cinemas, 3 ( 1$): 33-48$.

Cody, J. (1994). 'Interview with Peter Greenaway'. Erişim adresi: http://www.paristransatlantic. com / magazine / interviews / greenaway.html. Erişim Tarihi: 10 Eylül 2019.

Di Stefano, J. (2008). "Peter Greenaway and the Failure of Cinema". Willoquet-Maricondi, P. ve Alemany-Galway, M. (Eds.). Peter Greenaway's Postmodern / Poststructuralist Cinema (s.37-50): Scarecrow Press.Toronto.

Enli, G. (2017). "New Media and Politics". Annals of the International Communication Association, DOI: $10.1080 / 23808985.2017 .1392251$

Glen Creeber, G. ve Martin, R. (2009). Digital Cultures: Understanding New Media: Open University Press.

Gardner, J. (2009). “Greenaway's suitcase cinema and new media archaeology". Studies in European Cinema, 5 (2): 143-153.

Hawthorne, C. (1997). 'The Peter Greenaway Interview'. Erişim adresi: http://www.salon.com/ june97/greenaway2970606.html. Erişim Tarihi: Mayıs 2016.

Lister, M. (2003). New media: A critical introduction. Oxon: Routledge.

Manovich, L.( 2001). The Language of New Media: MIT Press. USA.

Manovich, L. (2003). "New Media from Borges to HTML". The New Media Reader, 1 :13-25.
Molinari, C. (2018). "In Between the Arts: Peter Greenaway and Sergei Eisenstein". Quarterly Review of Film and Video. DOI: $10.1080 / 10509208.2018 .1434753$

Murray, J. H. (1998). Hamlet on the Holodeck: The Future of Narrative in Cyberspace. Cambridge, MA: MIT Press.

Murray, J. H.( 2011). Inventing the Medium: Principles of Interaction Design as a Cultural Practice.:Cambridge, MA: MIT Press.LondonEngland

Rice, R. E. (1999). Artifacts and Paradoxes in New Media. New Media \&Society, 1 (1): 24-32.

Ryan, M. L. (2006). Avatars of Story. Minneapolis, MN: University of Minnesota Press.

Sampson, P. (1995). "Interview with Peter Greenaway". Third Way, 18 (10): 12-15.

Shah, N. (2009 ).'Now streaming on your nearest screen: Contextualizing new digital cinema through Kuso'. Journal of Chinese Cinemas. 3 (1): 15-31.

Street, S. (1997). British National Cinema:Routledge. London-England.

Tulseluperjourney. (2019). http: / / www. tulseluperjourney.com/about.jsp. Erişim Tarihi: 5 Eylül 2019.

Visitworldheritage. (2019). Erişim Tarihi: 10.12.2019. https: / / visitworldheritage.com/en / eu/venus-ofwillendorf/e66a1f89-7b74-4dbe-b1af-9becbb2b87e9

Willoquet-Maricondi, P., Alemany-Galway, M. (2008). Introduction: A Postmodern/ Poststructuralist Cinema. İçinde. Peter Greenaway's Postmodern/Poststructuralist Cinema Der: Paula Willoquet-Maricondi \& Mary Alemany-Galway (s. xiii-3). Toronto: The Scarecrow Press.

Willoquet-Maricondi (2008). "Peter Greenaway's postmodern/poststructuralist cinema". WilloquetMaricondi, P. ve Alemany-Galway, M. (Eds.). Peter Greenaway's Postmodern / Poststructuralist Cinema (s.3-36): Scarecrow Press. Toronto.

Young, R.( 2014). "Remembering Bogle Chandler: an exploration of new media's storytelling potential". Digital Creativity. 25 (2): 97-112. 